\title{
The Caddo Occupation of the L. B. Miller Farm (41HE4/55) in the Post Oak Savanna and Trinity River Basin in East Texas
}

Timothy K. Perttula

Heritage Research Center, Stephen F. Austin State University

Follow this and additional works at: https://scholarworks.sfasu.edu/ita

Part of the American Material Culture Commons, Archaeological Anthropology Commons, Environmental Studies Commons, Other American Studies Commons, Other Arts and Humanities Commons, Other History of Art, Architecture, and Archaeology Commons, and the United States History Commons

Tell us how this article helped you.

This Article is brought to you for free and open access by the Center for Regional Heritage Research at SFA ScholarWorks. It has been accepted for inclusion in Index of Texas Archaeology: Open Access Gray Literature from the Lone Star State by an authorized editor of SFA ScholarWorks. For more information, please contact cdsscholarworks@sfasu.edu. 


\section{The Caddo Occupation of the L. B. Miller Farm $(41 \mathrm{HE} 4 / 55)$ in the Post Oak Savanna and Trinity River Basin in East Texas}

\section{Creative Commons License}

(c) (1) (8)

This work is licensed under a Creative Commons Attribution-NonCommercial 4.0 International License 


\section{The Caddo Occupation of the L. B. Miller Farm (41 HE4/55) in the Post Oak Savanna and Trinity River Basin in East Texas}

Timothy K. Perttula

\section{Introduction}

The L. B. Miller Farm site (41HE4/55) is a Late Caddo period Frankston phase Caddo habitation site and small cemetery on an upland landform (400 ft. amsl) in the Coon Creek-Catfish Creek drainage in the Post Oak Savannah of the Trinity River basin (Figure 1). The ancestral Caddo artifact collections from the site at the Texas Archeological Research Laboratory at The University of Texas at Austin (TARL) include four vessels from a burial feature, sherds from two unreconstructed ceramic jars found in habitation contexts, and 178 ceramic sherds from midden deposits.

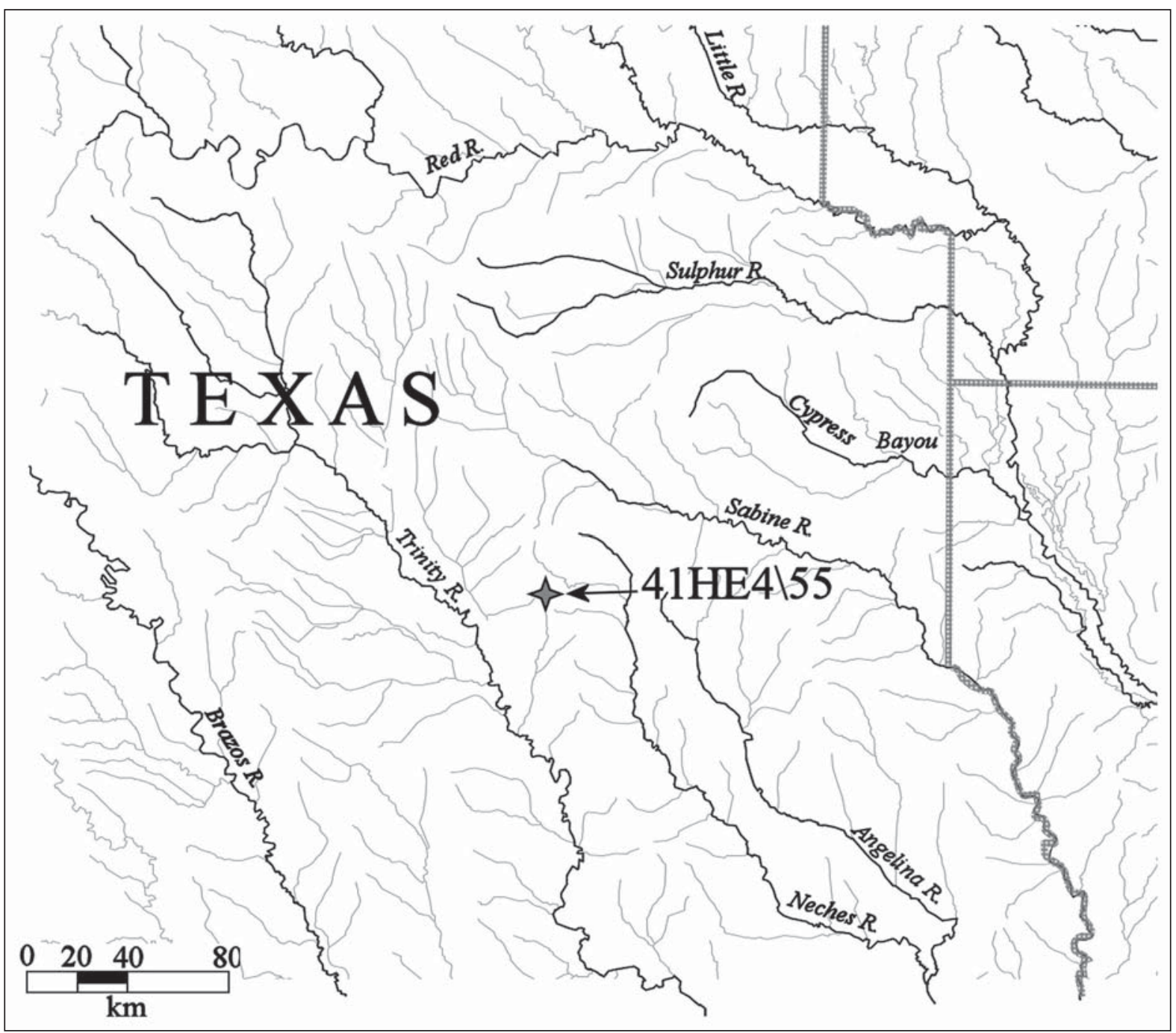

Figure 1. Location of the L. B. Miller Farm site in East Texas. 


\section{0 and 1934 Investigations}

Caddo ceramic vessels from a burial in an unmarked cemetery were exposed in a gully in 1920 on the L. B. Miller Farm, where they were collected by the landowner's son. These four vessels were obtained by J. E. Pearce of the University of Texas (UT) on long-term loan that year. In November 1935, UT archaeologists led by A. M. Woolsey returned to the site to try to locate and excavate additional Caddo burial features (Woolsey 1935). An area at least $20 \mathrm{ft}$. in each direction from the 1920 burial feature location was excavated by UT, but no other burial features were located.

UT archaeologists also excavated another place on the site an unknown distance southwest of the burial feature, in an area that apparently had midden deposits (Woolsey 1935). This area had sherds from two different unreconstructed ceramic jars as well as a number of sherds from unrelated plain ware, fine ware, and utility ware vessels.

\section{Ceramic Vessels}

The four vessels from the ancestral Caddo burial feature exposed in 1920 at the L. B. Miller Farm site include a Killough Pinched jar body section, a Poynor Engraved, var. unspecified bottle, a Hood Engraved, var. unspecified effigy bowl (missing the effigy head), and a Poynor Engraved, var. $N$ carinated bowl. These types and varieties are consistent with the burial feature dating to some portion of the Frankston phase (ca. A.D. 1400-1680).

SITE NAME OR SITE NUMBER: L. B. Miller Farm

VESSEL NO.: 1

VESSEL FORM: Jar body section

NON-PLASTICS AND PASTE: grog

RIM AND LIP FORM: N/A

CORE COLOR: F (fired in a reducing environment and cooled in the open air)

INTERIOR SURFACE COLOR: yellowish-brown; fire clouds on the body and base

EXTERIOR SURFACE COLOR: yellowish-brown; fire clouds on the rim, body, and base

WALL THICKNESS (IN MM): body, $7.6 \mathrm{~mm}$

INTERIOR SURFACE TREATMENT: smoothed

EXTERIOR SURFACE TREATMENT: none

HEIGHT (IN CM): $10.2 \mathrm{~cm}$, body section

ORIFICE DIAMETER (IN CM): Unknown

DIAMETER AT BOTTOM OF RIM OR NECK (IN CM): 10.8

BASE DIAMETER (IN CM) AND SHAPE OF BASE: 7.6; circular and flat

ESTIMATED VOLUME (IN LITERS): 0.66+ 
DECORATION (INCLUDING MOTIF AND ELEMENTS WHEN APPARENT): The lowermost portion of the rim section has remnants of horizontal pinched ridges. The vessel body has curvilinear and concentric pinched ridges that cover the vessel body to within $1.0 \mathrm{~cm}$ of the vessel base.

PIGMENT USE AND LOCATION ON VESSEL: none

TYPE AND VARIETY (IF KNOWN): Killough Pinched (see Suhm and Jelks 1962:Plate 46g)

SITE NAME OR SITE NUMBER: L. B. Miller Farm

VESSEL NO.: 2

VESSEL FORM: Bottle with a carinated body

NON-PLASTICS AND PASTE: grog

RIMAND LIP FORM: Direct rim and a flat lip

CORE COLOR: $G$ (fired in a reducing environment and cooled in the open air)

INTERIOR SURFACE COLOR:

dark grayish-brown

EXTERIOR SURFACE COLOR: yellowishbrown; fire clouds on the rim, body, and base

WALL THICKNESS (IN MM): rim, $5.8 \mathrm{~mm}$

INTERIOR SURFACE TREATMENT: none

EXTERIOR SURFACE

TREATMENT: smoothed

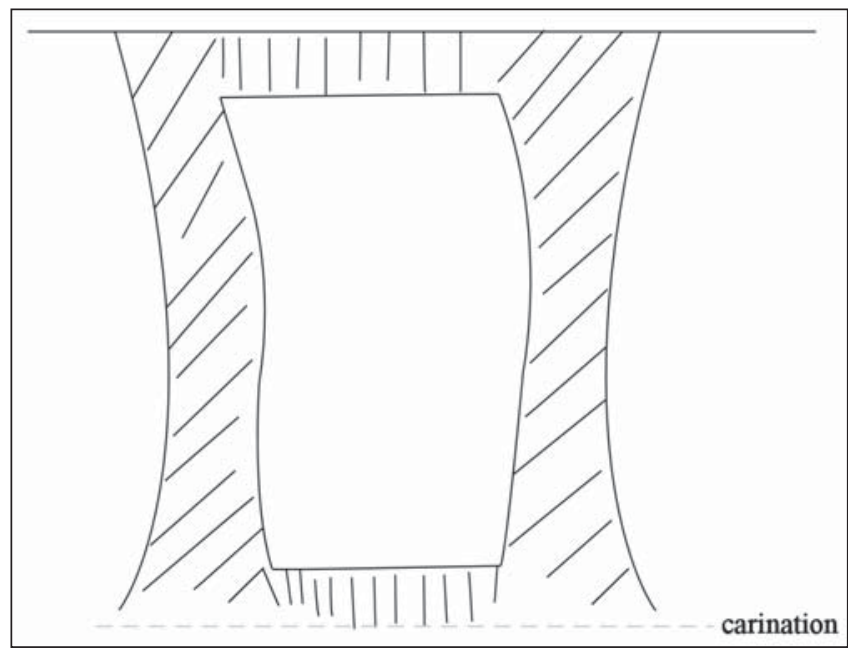

Figure 2. Decorative elements on Poynor Engraved, var. unspecified bottle (No. 2) from the L. B. Miller Farm (41HE4/55).

HEIGHT (IN CM): 17.8

ORIFICE DIAMETER (IN CM): 4.4

DIAMETER AT BOTTOM OF RIM OR NECK (IN CM): $5.6 \mathrm{~cm}$; maximum body diameter is $12.8 \mathrm{~cm}$

BASE DIAMETER (IN CM) AND SHAPE OF BASE: 7.5; circular and flat

ESTIMATED VOLUME (IN LITERS): 0.55

DECORATION (INCLUDING MOTIF AND ELEMENTS WHEN APPARENT): the vessel body has two opposing sets of large diagonal hatched engraved brackets that extend from the top of the vessel body to the vessel carination (Figure 2). Between the large hatched brackets are narrow rectilinear engraved zones filled with short vertical lines.

PIGMENT USE AND LOCATION ON VESSEL: none

TYPE AND VARIETY (IF KNOWN): Poynor Engraved, var. unspecified 
SITE NAME OR SITE NUMBER: L. B. Miller Farm

VESSEL NO.: 3

VESSEL FORM: Bowl, with tab tail (34 x $10 \mathrm{~mm}$ in length and width); effigy head attachment is missing NON-PLASTICS AND PASTE: grog

RIM AND LIP FORM: Direct rim and rounded lip

CORE COLOR: $\mathrm{G}$ (fired in a reducing environment and cooled in the open air)

INTERIOR SURFACE COLOR: grayish-brown

EXTERIOR SURFACE COLOR: black slip overlying yellowish-brown surface

WALL THICKNESS (IN MM): rim, $6.4 \mathrm{~mm}$

INTERIOR SURFACE TREATMENT: smoothed

EXTERIOR SURFACE TREATMENT: burnished

HEIGHT (IN CM): 5.1

ORIFICE DIAMETER (IN CM): 9.5

DIAMETER AT BOTTOM OF RIM OR NECK (IN CM): N/A

BASE DIAMETER (IN CM) AND SHAPE OF BASE: 6.4; circular and flat

ESTIMATED VOLUME (IN LITERS): 0.2

DECORATION (INCLUDING MOTIF AND ELEMENTS WHEN APPARENT): There are two broad horizontal engraved lines on the upper part of the vessel.

PIGMENT USE AND LOCATION ON VESSEL: none

TYPE AND VARIETY (IF KNOWN): Hood Engraved, var. unspecified (Perttula 2011:271), probably var. Hood

SITE NAME OR SITE NUMBER: L. B. Miller Farm

VESSEL NO.: 4

VESSEL FORM: Carinated bowl

NON-PLASTICS AND PASTE: grog

RIM AND LIP FORM: Inverted rim and rounded lip

CORE COLOR: $\mathrm{F}$ (fired in a reducing environment and cooled in the open air) 
INTERIOR SURFACE COLOR: yellowish-brown; fire clouds on the rim, body, and base

EXTERIOR SURFACE COLOR: yellowish-brown; fire clouds on the rim, body, and base

WALL THICKNESS (IN MM): rim, $7.3 \mathrm{~mm}$

INTERIOR SURFACE TREATMENT: smoothed

EXTERIOR SURFACE TREATMENT: smoothed

HEIGHT (IN CM): 13.4

ORIFICE DIAMETER (IN CM): 18.5

DIAMETER AT BOTTOM OF RIM OR NECK (IN CM): 22.5

BASE DIAMETER (IN CM) AND SHAPE OF BASE: 9.5; circular and flat

ESTIMATED VOLUME (IN LITERS): 2.2

DECORATION (INCLUDING MOTIF AND ELEMENTS WHEN APPARENT): The rim is divided into six panels by a series of opposed and oval-shaped hatched brackets (Figure 3). In each panel is a single engraved hooked arm element formed by two or more closely-spaced engraved lines.

PIGMENT USE AND LOCATION ON VESSEL: none

TYPE AND VARIETY (IF KNOWN): Poynor Engraved, var. N (Perttula 2011:Figure 6-65)

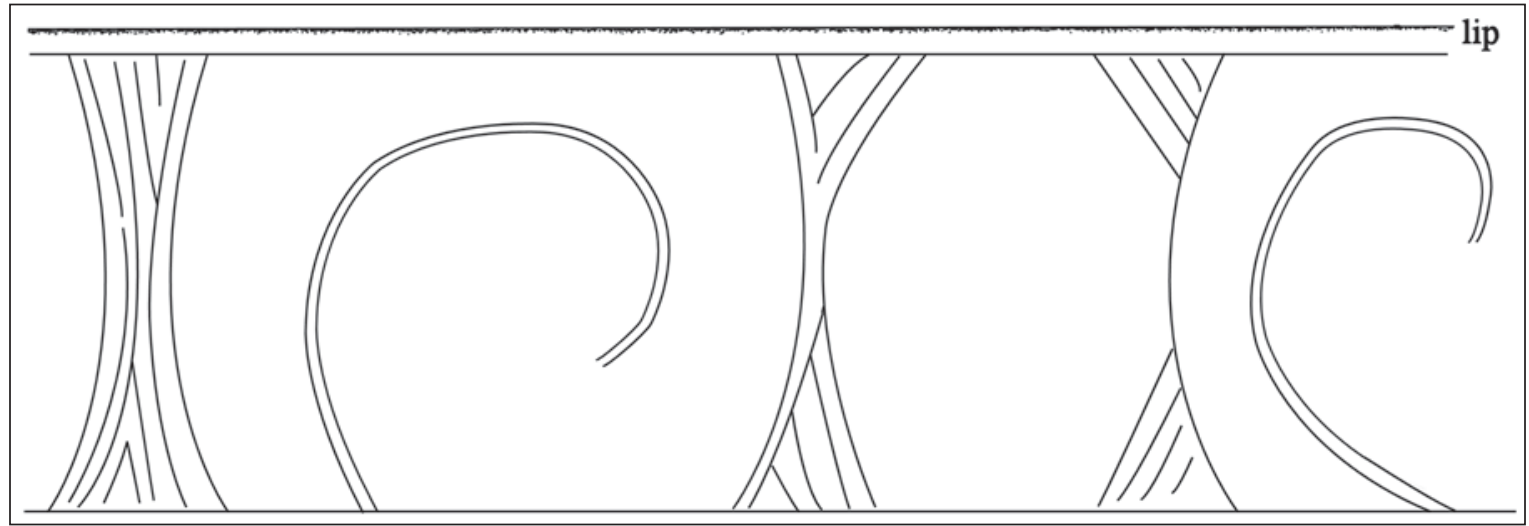

Figure 3. Poynor Engraved, var. $N$ carinated bowl (No. 4) from the L. B. Miller Farm site (41HE4/55).

\section{Ceramic Vessel Sherds}

Based on a 1985 TARL inventory prepared by Dr. Dee Ann Story, the first of the unreconstructed ceramic vessels from the L. B. Miller farm is a large jar with two opposed handles and an incised decoration on the rim. That decoration consisted of upper and lower horizontal incised lines on the rim panel as well as an unknown number of sets of three diagonal incised lines, pitched right to left. The second unreconstructed vessel is about 33 percent of a large Maydelle Incised jar represented by 35 rim sherds: the rim sherds had incised-punctated elements, and the body sherds had brushed decorative elements. 
The 178 other sherds from the midden deposits at the L. B. Miller Farm site include sherds from plain ware, fine ware, and utility ware vessels (Table 1). No information on the temper of these wares was provided on the TARL inventory, but it is likely that the majority of the sherds were from vessels tempered with grog, as is the case in the nearby Caddo Creek valley in the upper Neches River basin (Perttula and Walters 2016).

Table 1. Ceramic wares from the L. B. Miller Farm (41HE4/55).

\begin{tabular}{lllll}
\hline Ware & Rim & Body & Base & N \\
\hline Plain & 3 & 93 & 12 & 108 \\
Fine & - & 7 & - & 7 \\
Utility & 12 & 51 & - & 63 \\
\hline Totals & 15 & 151 & 12 & 178 \\
\hline
\end{tabular}

The plain to decorated sherd ratio of the L. B. Miller Farm site ceramic assemblage is 1.54. Approximately 51.4 percent of the decorated sherds have brushed decorative elements, while 40 percent have wet paste decorations (i.e., incised, incised-punctated). The brushed/wet paste ratio in the sherd assemblage is 1.29. These assemblage metrics in the midden deposits at the site are consistent with a ca. A.D. 1400-1480 Frankston phase occupation (see Perttula and Walters 2016).

Fine ware sherds in the assemblage only account for 10 percent of the decorated sherds (see Table 1). None of them were described or typologically identified on the TARL inventory. The utility wares include 35 brushed body sherds and one brushed-incised body sherd, both likely from Bullard Brushed jars; 19 punctated sherds; two incised-punctated sherds likely from Maydelle Incised jars; and six Maydelle Incised rim and body sherds;

\section{Summary and Conclusions}

The L. B. Miller Farm site (41HE4/55) is an ancestral Caddo habitation site and cemetery of unknown size on Coon Creek in the Post Oak Savannah in the Trinity River basin in East Texas. UT archaeologists first investigated the site in 1920, when the landowners loaned them four ceramic vessels that had been eroded from a burial feature, and then again in 1935, when excavations failed to identify any additional Caddo burial features but did identify midden deposits with sherds from two large, but unreconstructed ceramic jars as well as 178 other ceramic sherds.

The analysis of the ceramic vessels and an examination of an 1985 TARL inventory of the sherds indicates that the L. B. Miller Farm site was occupied during the Frankston phase of the Late Caddo period; the vast majority of known Frankston phases are in the Neches River basin, and there is a particular concentration of Frankston phase sites in the adjoining Caddo Creek valley in the upper Neches River basin (Perttula and Walters 2016). Ceramic plain and decorated sherd metrics suggest that the midden deposits may have accumulated during the early part of the Frankston phase, from ca. A.D. 1400-1480. The temporal sequence of Poynor Engraved varieties and other engraved fine wares in the upper Neches River basin (see Perttula 2011:Table 6-37) when compared to the few ceramic vessels from the burial feature suggest the deceased at the L. B. Miller Farm site was interred in the later part of the Frankston phase, from ca. A.D. 1560-1680.

\section{Acknowledgments}

Thanks to Jonathan Jarvis at TARL for facilitating the study of the vessels from the L. B. Miller Farm site. Lance Trask prepared the figures for this article. 


\section{References Cited}

Perttula, T. K.

2011 The Ceramic Artifacts from the Lang Pasture Site (41AN38) and the Place of the Site within an Upper Neches River Basin Caddo Ceramic Tradition. In Archeological Investigations at the Lang Pasture Site (41AN38) in the Upper Neches River Basin of East Texas, assembled and edited by T. K. Perttula, D. B. Kelley, and R. A. Ricklis, pp. 145-320. Archeological Studies Program Report No. 129, Texas Department of Transportation, Environmental Affairs Division, Austin.

Perttula, T. K. and M. Walters

2016 Caddo Archaeology in the Caddo Creek Valley of the Upper Neches River Basin, Anderson and Henderson Counties, Texas. Special Publication No. 43. Friends of Northeast Texas Archaeology, Austin and Pittsburg, in press.

Suhm, D. A. and E. B. Jelks (editors)

1962 Handbook of Texas Archeology: Type Descriptions. Special Publication No. 1, Texas Archeological Society, and Bulletin No. 4, Texas Memorial Museum, Austin. Reprinted in 2009, Gustav's Library, Davenport, Iowa.

Woolsey, A. M.

1935 Burial Site, L. B. Miller Farm, 7 Miles south of Athens, Henderson County, November 23, 1935. MS on file, Texas Archeological Research Laboratory, The University of Texas at Austin. 